\title{
Water Potentiality of Sustainable Management Challenges in the Oued Souf Region, south east Algeria
}

\author{
Miloudi Abdelmonem ${ }^{1}$, Remini Bouallem ${ }^{2}$ \\ ${ }^{1}$ Department of Hydraulics and Civil Engineering, University of El Oued Algeria \\ ${ }^{2}$ Department of Water Science, Saad Dahlebe University of Blida Algeria \\ E-Mails: monem_mld@yahoo.fr
}

\begin{abstract}
Water is the most essential product of life and is a part of the essential constitution of living cells; it helps to carry out all the vital operations. Water is a cosmic element, in the same way as the sun and the earth. With the population growth in the Souf region, the needs of habitats and farmers increase for water. These needs have a negative consequence on the serene life of the people; the phenomenon of the upwelling of the free water table has taken a very alarming dimension during the last twentieth century.

In our study, we focused our intention in the mechanism of the drawdown of the waters of the aquifer CT of state AL Oued (South East Algeria) and the consequences of irrational overexploitation of this aquifer on the environment of the region.
\end{abstract}

Keywords: the water, Souf region, CT, Overexploitation.

\section{NOMENCLATURE}

CT: complex terminal

DRH: Direction of Hydraulic Resources

DTM: Digital Terrain Model

AEP: Drinking Water Supply

\section{INTRODUCTION}

If man maintains singular relations with water, it is because of the absolute necessity in which he finds himself appealed to it simply to stay alive. It is impossible in these circumstances, to take a step back. Twenty-four hours without it and the finest intellectual machine stops, the brain does not hear its thirst.

The traditional water supply system for the inhabitants and farmers, Operate in a closed loop, with limited flows. The deep drilling has created additional crises, without planning any exits. The system is now disturbed.

The problem of water surpluses does not only affect the city of Oued, but it also affects several other towns in the Algerian Sahara, as example Ouargla region and Touggourt region;

Those are large cities, where the volumes of which have developed great perimeters of putting in values, which discharge considerable amount of drainage water.

This fast development has led to enormous problems in recent years, mainly related to the upwelling and evacuation of water from groundwater, to the sewerage water.

Our work is based on the hydro geological part, to be able to realize the drawdown of the level of the deep water table of complex terminal of the region of the Souf (Algeria) or by a word overexploitation of CT. 


\section{THE GEOGRAPHICAL SITUATION OF THE OUED SOUF REGION}

The study area is located in the Wilaya of El Oued, One of the main oases of the Algerian northern Sahara. The study area covers 18 municipalities (El Oued, Bayadha, Robbah, Kouinine, Guemar, Taghzout, Hassani Abdelkrim, Debila, Sidi Aoun, Magrane, Hassi Khelifa, Reguiba, Mihouensa, Oued Alenda, Ogla, Nakhla, Ourmes et Trifaoui), An area of approximately $11200 \mathrm{Km} 2$, limited by the following geographical coordinates: Longitude: $06^{\circ} 20^{\prime}$ 'and $07^{\circ} 50^{\prime}$ East and latitudes; $32^{\circ} 50$ 'and $34^{\circ} 30^{\prime}$ North (Figure 1).

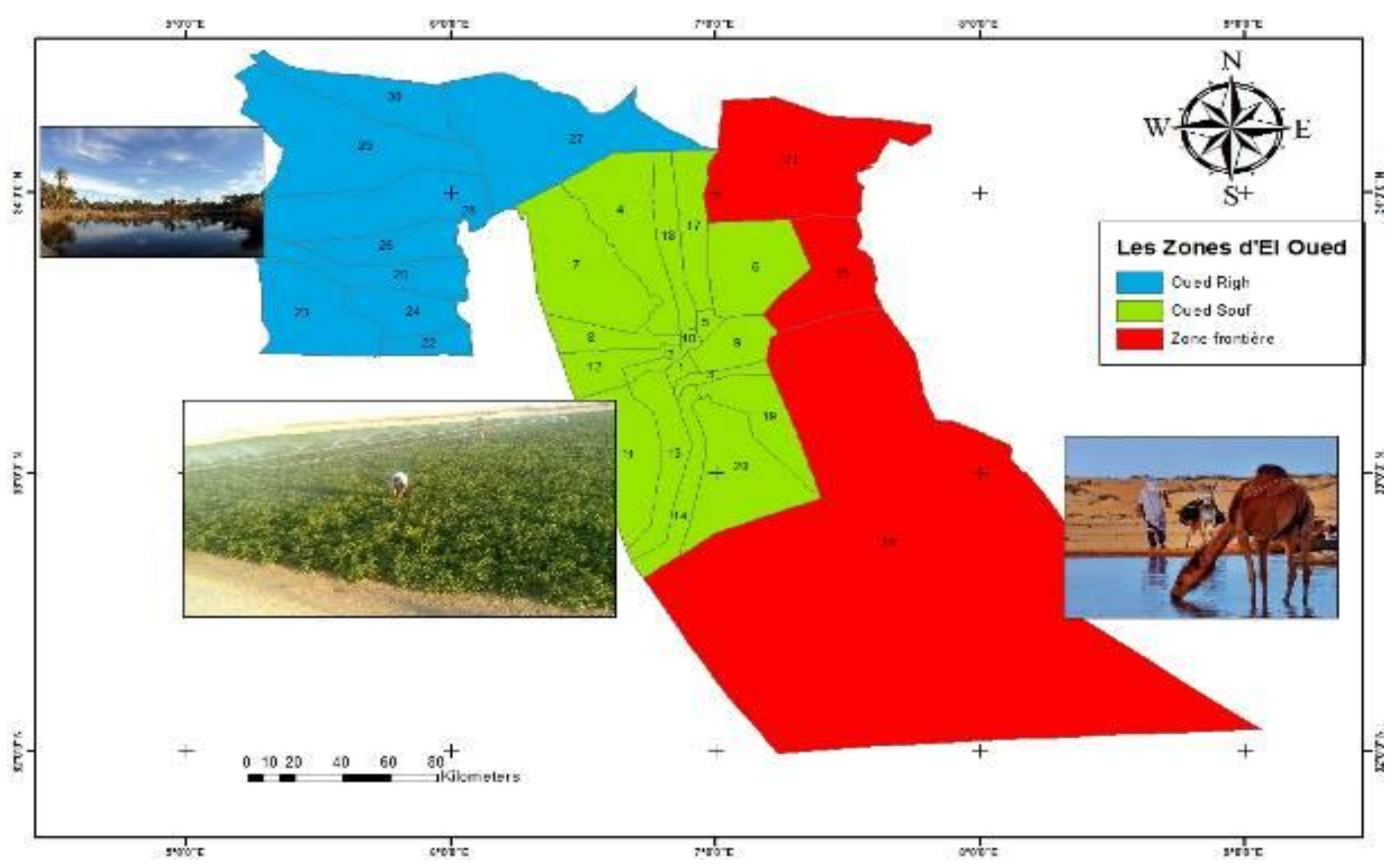

Fig1. Areas (sectors) in the state of El Oued (A. Miloudi 2015)

1.El Oued 2.Kouinine 3.Bayadha 4.Guemar 5.Debila 6.Hassi Khalifa 7.Reguiba 8.Taghzout 9.Trifaoui 10.Hassani A-Karim 11. Oued El Alenda 12. Ourmes 13.Mih Ouensa 14.Robbah 15.Taleb El Arbi 16.Douar El Maa 17.Magrar 18.Sidi Aoun 19.Nakhla 20.El Ogla 21. Ben Ghecha 22.Sidi Amrane 23.M'Rara 24.Djamaa 25.Tendla 26.Sidi Khellile 27. Hamraia 28. El Mghair 29. Oum Tiour 30.Still

The only water resources available are underground aquifers [1]. The underground water tables of the Souf region are contained in aquifer formations of a different nature especially on the national and regional scale of the country. The authors (Baba SY, 2005, Brl-bneder, 1999, Cornet 1961, Castany 1982, Cornet and Gouscov 1952, Guendouz A, et al., 2003, UNESCO, 1972a) [2-5]. Generally distinguishes three geological complexes that contain groundwater resources: A vast sedimentary basin consisting of layers of varying thickness and hydrogeological characteristics are: 1-Continental Intercalary. 2 Complex terminal. 3- Groundwater.

\section{THE CT PIEZOMETRY OF THE SOUF REGION}

\section{3-1 Terminal complex piezometric map of 2012:}

Measurements of the piezometric level (pressure) in the Saharan boreholes face many problems:

- The first problem is the absence or very limited number of true piezometers specifically designed for measurements due to important depths (Case of Continental Intercalary) which will be resulting in prohibitive costs of piezometers. The piezometric measurements are therefore generally made on boreholes in operation, which implies stopping pumping or closing the drilling, if it is artesian, for at least several hours.

This operation runs up against the reluctance of the users who are thus deprived of water, for a certain time. For our study, the ANRH carried out twelve 12 boreholes (piezometers for monitoring) distributed geographically on the Souf region.

- The second problem is related to the difficulty of measuring the gushing boreholes, the closure of which is not always possible and which are not always equipped with an outlet upstream of the valve to connect the manometer. In general, a measurement was made at the time of drilling. With the help of the Database of 
Direction of Hydraulic Resources (DRH) state of El Oued, Concerning the piezometric level for new boreholes drilled or drilled their pump (broken down) during the year 2012

Using ArcGIS, a Digital Terrain Model (DTM) of the Souf region is added as a background and the borehole data is interpolated to extract the piezometric map of Terminal Complex CT (figure 02)

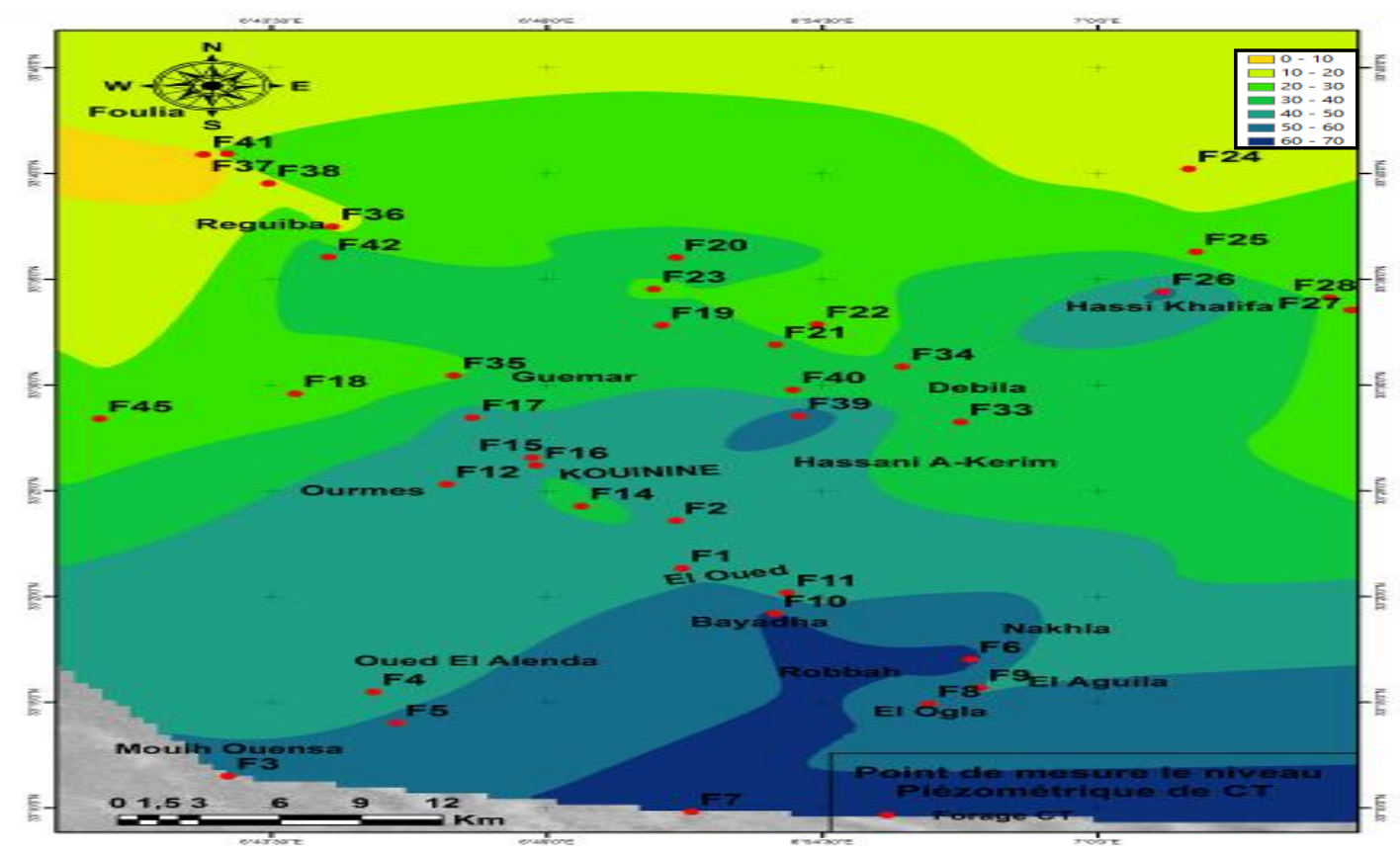

Fig2. CT piezometric map of the Souf region in 2012

According to the previous map, overexploitation of the aquifer at the common Robbah, Bayadha, Hassani A. Karim and Hassi Khalifa is clear, due to the need for Drinking Water Supply (AEP).

The Hassi Khalifa common DWS network is connected to the Barremian (Continental Intermediate) drilling to cover water requirements, and some CT drilling for irrigation.

The water requirement for the common Hassani A-Karim is distributed between the AEP, irrigation and need of the industrial zone. The piezometric level at level F14 (common Kouinine) is high compared to other boreholes "F2, F12, F15, F16", because it is not in service a few years i.e. When we return to the Nesson C in 1978 (Figure 03) piezometric level map. We found that the communes El Oued, Kouinine, Guemar and Reguiba ... etc. Or rather the northern part of the Souf is characterized by deep artesian (complex Terminal) artesian.

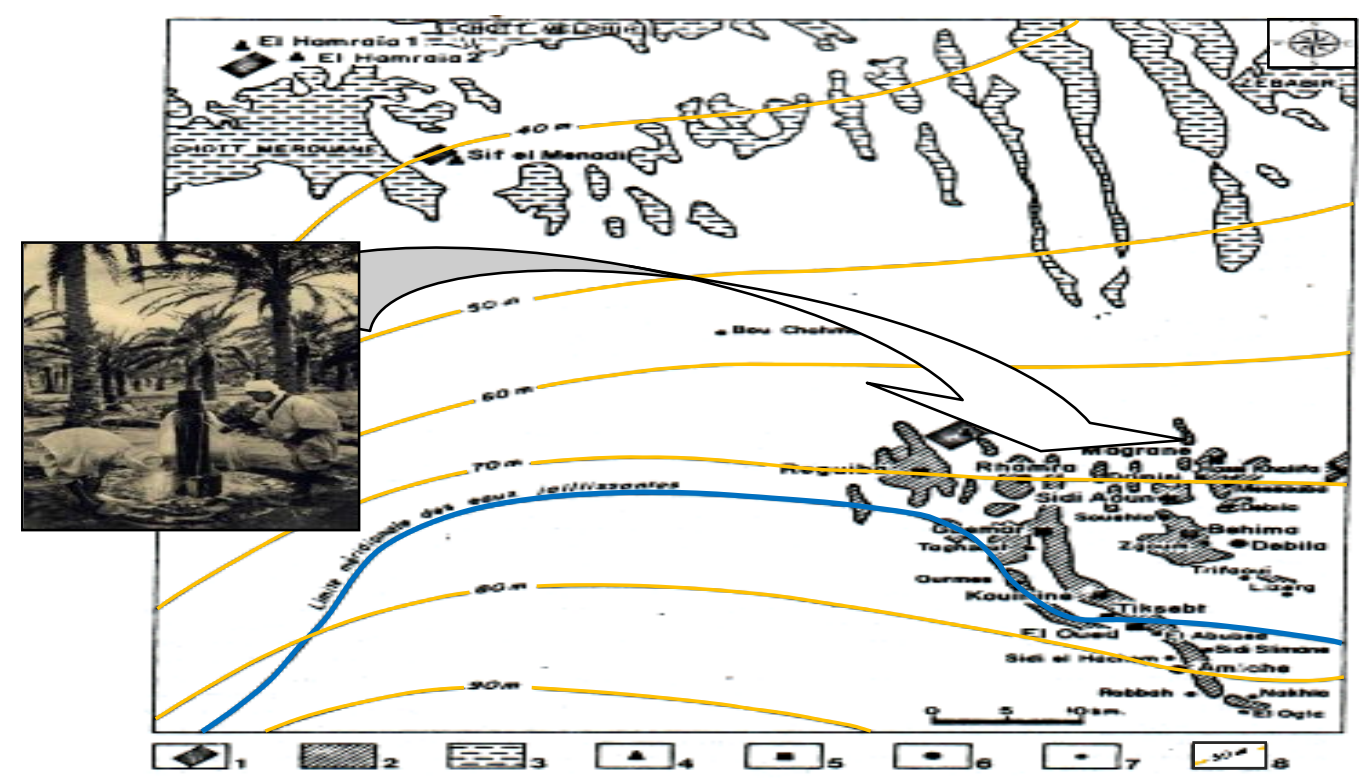

Fig3. CT piezometric map of the Souf in 1967(Nesson. C, 1978) 
Irrigated palm grove. - 2. Palmeraie "Bour". - 3. Chott; Sebkha. - 4. Wells used for irrigation. 5. Wells for the supply of drinking water. - 6. Well not exploited. -7. Locality without well. - 8. Isopieze of the Terminal Complex (Lower EocenePontian). The greasy trais in blue marks the southern limit of the gushing waters of the Complex Terminal.

For this reason, we have built a 3D model by Arc Scene; Presents the zones that it had of CT artesian artery (Figure. 4).

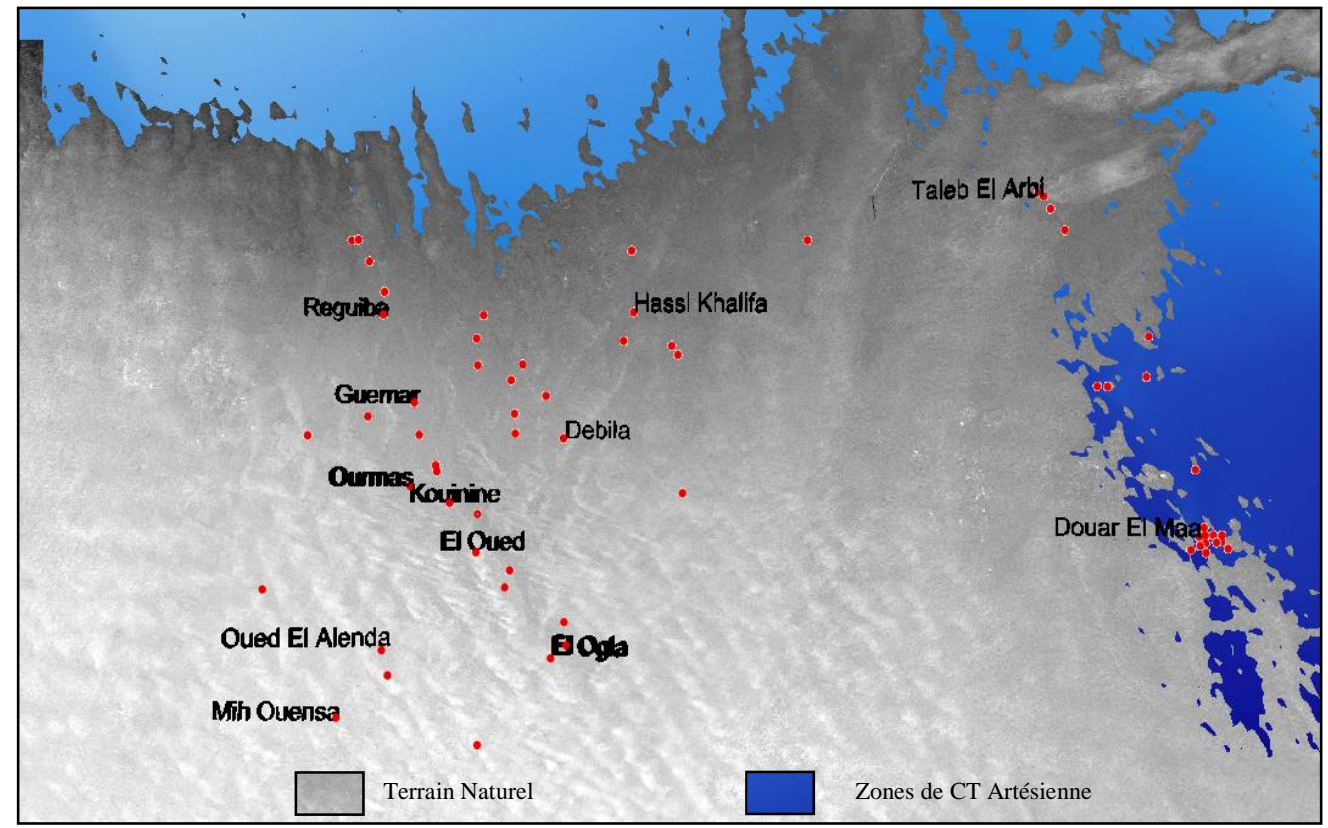

Fig4. CT artesian areas in 2012

According to the drilling inventory (DRH, 2015) the flow extracted every day is approximately 3447.42 liters per second, this model clearly explains that the artesian water table was lost due to overexploitation of this source.

\section{CONCLUSION}

The increase in pumped volumes and the development of Saharan agriculture have repercussions at the level of these Saharan aquifers (CT) in the form of the drying up of the sources and the weakening or losing of artesianism as in our region. This increasing exploitation is likely to lead to changes in water quality in the vulnerable zones (Salt and mineral concentrations) over the long term. Our study is insufficient to give total coverage on the water resources below us feet, for this it is of plan of work in 2016 with the group ANRH of Touggourt concerned the hydrodynamics and hydrochemistry of complex terminal and continental Intercalary of the region Oued Souf and Oued Righ. We also pence this work with the three tablecloths or rather the three subtablets that make up the complex terminal.

\section{REFERENCE}

[01] Voisin A.R., 2004. Les Souf monographie, Edition El-Walid, El Oued-Algérie. 319 p.

[02] Baba Sy M., Besbes M., 2006. Holocene recharge and present recharge of the Saharan aquifers. A study by numerical modelling, Colloque international - Gestion des grands aquifères - 30 mai-1er juin 2006, Dijon, France. 16p.

[03] Cornet A., 1961. Initiation à l'hydrogéologie saharienne. Cours ronéoté destiné aux officiers du cours préparatoire aux Affaires sahariennes. S.E.S. Birmandreis, Alger, 108p.

[04] Castany G., 1982. Bassin sédimentaire du Sahara septentrional (Algérie Tunisie). Aquifères du continental intercalaire et du complexe terminal. Bull. BRGM 2 III, Vol. 2. pp 127-167.

[05] Guendouz A., Moulla A.S., Edmunds W.M., Zouari K., Shand P., Mamou A., 20 May 2003. Hydrogéochemical and isotopic evolution of water in the Complexe Terminal aquifer in the Algerian Sahara, Hydrogeology Journal (2003). pp 485-495.

[06] Nesson C., 1978. L'évolution des ressources hydrauliques dans les oasis du Bas Sahara algérien. In: Recherche sur l'Algérie. Ed. CNRS, Paris. pp 7-100. 